\title{
MODEL KAMPANYE PERUBAHAN BUDAYA ORGANISASI PT KAZETO PUTRA PERKASA
}

\author{
Dimas Ramdhani Triputra \\ Public Relations, Magister Ilmu Komunikasi, Universitas Budi Luhur \\ Dimas.ramdhani@gmail.com.
}

\begin{abstract}
ABSTRAK
Penelitian ini memiliki tujuan untuk mendeskripsikan bagaimana proses kampanye perubahan budaya organisasi PT Kazeto Putra Perkasa. Pada penelitian ini menggunakan paradigma konstruktivisme dan digunakan analisis deskriptif kualitatif. Berdasarkan hasil analisis bahwa PT Kazeto Putra Perkasa melaksanakan kampanye perubahan budaya organisasi dengan jenis kampanye Ideological or Cause- Oriented Campaigns yang bertujuan bersifat khusus dan berdimensi perubahan sosial (social change campaings) dari budaya lama ke budaya baru. Dimana tipe kampanye yang digunakan, yaitu Campaigns Model of Succesful Organization (Model Kampanye Organisasi yang Sukses) dengan mendefinisikan misi atau pernyataan nilai-nilai yang diinginkan oleh perusahaan, mengkomunikasikan budaya nilai-nilai perusahaan, membangun hubungan publik yang positif, dan reputasi perusahaan. Untuk mengkampanyekan perubahan budaya organisasi PT Kazeto Putra Perkasa dari 7 nilai: Integritas, Profesional, Keteladanan, Kekeluargaan, Kemashalatan, Kepuasan Pelanggan, dan Penghargaan SDM menjadi tata nilai kerja, yaitu: Integrity, Speed, Smart, Service Excellent (Komptensi inti) dan Efektif, Efisiensi, Inovatif, dan Terintegrasi (Budaya Kerja), maka ditentukan tujuan yang hendak dicapai, sasaran kampanye, ruang lingkup kampanye, jangka waktunya, publik sasarannya, tema, topik atau isu dari kampanye, efek yang akan diinginkan dalam suatu kampanye, fasilitas, perlengkapan, atau sarana yang akan menunjang suatu kampanye, dan pembentukan team work yang solid dan profesional.
\end{abstract}

Kata Kunci: Komunikasi Organisasi, Kampaye, Budaya Organisasi 


\begin{abstract}
This study aims to describe how the campaign process changes the culture of PT Kazeto Putra Perkasa organization. In this study using the constructivism paradigm and used qualitative descriptive analysis. Based on the results of the analysis that PT Kazeto Putra Perkasa carried out a campaign to change organizational culture with the type of Ideological or Cause-Oriented Campaign campaigns that aimed specifically and with social change campaings from the old culture to the new culture. Where the type of campaign used, namely the Campaign Model of Successful Organizations by defining the mission or statement of values desired by the company, communicating the culture of corporate values, building positive public relations, and the reputation of the company. To campaign for the cultural change of PT Kazeto Putra Perkasa's organization from 7 values: Integrity, Professionalism, Exemplary, Kinship, Equipment, Customer Satisfaction, and HR Awards to become work values, namely: Integrity, Speed, Smart, Excellent Service (Core Competence) and Effective , Efficiency, Innovative, and Integrated (Work Culture), then determined the objectives to be achieved, campaign goals, campaign scope, time period, public targets, themes, topics or issues from the campaign, effects that will be desired in a campaign, facilities, equipment, or facilities that will support a campaign, and the formation of a solid and professional team work.
\end{abstract}

Keywords: Organizational Communication, Campaign, Organizational Culture 


\section{PENDAHULUAN}

Seiring dengan terjadinya kemajuan Teknologi Informasi dan Komunikasi (TIK) yang cepat di berbagai negara dapat menyebabkan terjadinya pergeseran yang tiba-tiba dan tidak terduga dalam dunia industri yang dikenal dengan Industri 4.0. Untuk itu perusahaan sebagai bentuk organisasi bergantung dan harus berinteraksi dengan lingkungan eksternal bila ingin kelangsungan hidup terjaga. Oleh karena itu, segala sesuatu yang tercakup dalam atau mengubah lingkungan dapat mempengaruhi berbagai operasi organisasi dan menyebabkan tekanan perubahan. Perubahan organisasi terjadi karena adanya perubahanperubahan dalam berbagai variabel eksternal, seperti sistem politik, ekonomi, teknologi, pasar dan nilai-nilai serta kekuatan-kekuatan perubahan internal ini merupakan hasil dari faktor-faktor seperti: tujuan, strategi, kebijaksanaan manajerial, dan teknologi baru, serta sikap dan perilaku karyawan. Kekuatankekuatan eksternal dan internal penyebab perubahan adalah sering saling berhubungan. Hubungan ini terutama merupakan hasil perubahan-perubahan dalam nilai-nilai dan sikap-sikap yang mempengaruhi orang dalam sistem. Orangorang dengan berbagai sikap baru memasuki organisasi dan menyebabkan perubahan dari dalam (Handoko, 2013:318).

Perubahan organisasi secara internal dimulai dari karyawan, kecenderungan perkembangan pada perusahaan-perusahaan sekarang memandang bahwa karyawan adalah sebuah faktor penting yang dapat meningkatkan reputasi yang membedakan antara satu perusahaan dengan yang lainnya. Selain itu, kemajuan suatu perusahaan pun tidak terlepas hasil kinerja karyawan dalam bekerja, sehingga sangat wajar jika karyawan dapat dinilai sebagai aset perusahaan yang paling berharga. Namun, dalam perkembangan industri 4.0 ini karyawan perlu menyesuaikan dan mengembangkan kompetensi agar dapat mampu bersaing. Pembinaan dan pengembangan karyawan perlu dilakukan sebagai upaya menyesuaikan diri dengan perubahan dan perkembangan karyawan. Selain itu perusahaan pun perlu melakukan penyamaan persepsi dengan para karyawannya, agar dapat mencapai tujuan perusahaan dengan cepat. Itu artinya, antara perusahaan dengan karyawan perlu terjalin interaksi yang selaras, baik secara top down mapun botton up.

Karyawan sebagai bagian dari kelompok dalam perusahaan memiliki serangkaian perilaku yang dianggap harus dilakukan oleh orang yang menduduki posisi yang bersangkutan dan yang benar-benar dilakukan oleh seseorang, dimana terjadi melalui sebuah interaksi. Interaksi dapat terjadi baik antar individu, kelompok, maupun organisasi melalui sebuah komunikasi. Dalam hal ini komunikasi dalam organisasi dapat terjadi melalui proses pengiriman dan penerimaan berbagai pesan organisasi di baik dalam kelompok formal, maupun informal dari suatu organisasi. Komunikasi dalam kehidupan organisasi dapat terjadi secara internal ketika proses penyampaian pesan antara anggota-anggota organisasi yang terjadi untuk kepentingan organisasi, baik antara secara vertikal (atasan dan bawahan) maupun horizontal (antar sesama karyawaan).

Budaya organisasi adalah sesuatu yang dihasilkan melalui interaksi sehari-hari dalam organisasi bukan hanya tugas pekerjaan, tetapi semua jenis 
komunikasi (Littlejhon dan Foss, 2011:383). Selain itu, budaya organisasi dapat berupa keseluruhan simbol, peristiwa, tradisi, standarisasi pola perilaku verbal, non verbal, cerita rakyat, aturan, dan ritual yang memberi organisasi ciri-ciri atau kepribadian (Ruben dan Stewart, 2013:346). Tujuan budaya adalah melengkapi para anggota dengan rasa (identitas) organisasi dan menimbulkan komitmen terhadap nilai-nilai yang dianut organisasi. Budaya perusahaan pada sisi yang sama merupakan penerapan nilai-nilai dalam suatu masyarakat yang terikat bekerja di bawah naungan suatu perusahaan (Kasali:109-110). Budaya organisasi tumbuh dari kegiatan komunikasi para anggota dan memainkan peran sentral dan meresap di dalam segala dinamika organisasi. Budaya organisasi yang dijalankan karyawan pun dapat disesuaikan dengan perkembangan perusahaan dalam upaya mencapai tujuan dalam menghadapi era industri 4.0. Dalam perubahan budaya organisasi berpeluang adanya resistensi yang terjadi pada karyawan, dikarenakan merasa nyaman dengan keadaan/budaya/aturan yang telah berjalan sebelumnya. Namun dalam proses selanjutnya fungsi Public Relations ikut serta untuk mengembangkan dan memelihara budaya perusahaan, sehingga pengaruh industri 4.0 dapat diterima sesuai kondisi perusahaan.

\section{LANDASAN TEORI}

\section{Peran Komunikasi dalam Organisasi}

Penelitian di dalam Jurnal ini dibuat oleh TA Gutawa (2010). Rumusan masalah dari penelitian ini adalah bagaimana peran komunikasi dalam organisasi. Tujuan dari penelitian ini adalah ingin mengetahui peran komunikasi dalam organisasi. Dalam penelitian ini, menggunakan analisis komunikasi organisasi dan budaya organisasi. Hasil dari penelitian ini adalah komunikasi organisasi bicara tentang pentingnya komunikator dalam memilih media yang akan digunakan dalam menyampaikan pesan kepada komunikan. Komunikator hanya menyampaikan pesan dan memilih media supaya pesan dapat diterima oleh komunikan, tanpa harus memperhitungkan bagaimana kelanjutan dari pesan yang disampaikan.

Budaya organisasi mengutamakan inovasi dan kretivitas anggota. Komunikasi yang bersifat "top-down" hanya memberikan instruksi-instruksi yang memerlukan pengembangan lebih lanjut, sedangkan para pengurus hanya melakukan apa yang digariskan oleh atasannya. Ini dikarenakan budaya hirarkhi organisasi yang membelenggu anggota untuk tidak berkreasi. Budaya organisasi memberi keluwesan anggota untuk mengembangkan potensi yang ada sesuai dengan nilai dan norma yang berlaku dalam organisasi. Budaya organisasi yang dipadukan dengan komunikasi organisasi akan menimbulkan rasa keterlibatan anggota dalam menjaga kelangsungan hidup organisasi.

\section{Peran Public Relations dalam Komunikasi Organisasi}

Penelitian ini dibuat oleh Ishak (2012) dengan rumusan masalah bagaimana suatu organisasi memanfaatkan public relations dalam menjalankan komunikasi organisasinya. Tujuan dari penelitian ini adalah ingin mengetahui suatu organisasi memanfaatkan public relations dalam menjalankan komunikasi 
organisasinya. Teori yang digunakan adalah teori komunikasi organisasi. Hasil dari penelitian ini menjelaskan komunikasi organisasi haruslah dipahami sebagai suatu komunikasi yang dijalankan organisasi kepada segenap publik yang dimiliki.

Komunikasi organisasi perlu ditangani oleh bagian yang khusus bertugas mengelola aktivitas komunikasi, dalam kaitan ini public relations merupakan jawaban yang tepat. Hal ini agar tidak terjadi overlaping tugas dengan bagian lain dalam organisasi. Komunikasi organisasi tidak bisa hanya dipahami sebatas tindakan kelembagaan (state of being) namun harus dipahami pula sebagai suatu cara atau pendekatan atau fungsi komunikasi (methode of communication). Sehingga sekalipun bagian yang menangani aktifitas komunikasi organisasi bukanlah bagian public relations, namun menggunakan atau mengedepankan fungsi atau pendekatan public relations maka harus dipahami sebagai tindakan public relations.

\section{Komunikasi Organisasi Dalam Mensosialisasikan Budaya Organisasi Prinsip 46 PT. Bank Negara Indonesia (Persero) Tbk, Kantor Cabang Utama Samarinda}

Penelitian ini dibuat oleh Nia Septiana Putri (2014). Rumusan masalah dari penelitian ini adalah bagaimana peran komunikasi dalam organisasi. Tujuan dari penelitian ini adalah ingin mengetahui:

1. komunikasi organisasi dalam mensosialisasikan budaya organisasi prinsip 46 .

2. Saluran media komunikasi yang digunakan komunikasi organisasi dalam mensosialisasikan budaya organisasi prinsip 46.

3. Hambatan komunikasi organisasi dalam mensosialisasikan budaya organisasi prinsip 46 PT BNI (Persero) Tbk. Kantor Cabang Utama Samarinda. Teori yang digunakan, yaitu Teori Pengurangan Ketidakpastian dan Teori Komunikasi Organisasi.

Dalam penelitian ini, menggunakan analisis deskriptif kualitatif.

Hasil dari penelitian ini menjelaskan komunikasi ke bawah telah tercipta berjalan dengan baik, pimpinan bidang operasional menyampaikan segala informasi yang diperlukan oleh karyawan secara terbuka dengan berusaha mengurangi ketidakpastian yang dirasakan karyawan seperti bersikap yang sesuai dengan budaya organisasi Prinsip 46 sebagai wujud contoh dan teladan bagi karyawan sehingga karyawan dapat mempercayai apa yang dikomunikasikan pimpinan tentang nilai-nilai budaya organisasi Prinsip 46. Komunikasi kelompok kecil lebih sering dilakukan dengan pengarahan lisan melalui rapat dan diskusi. Saluran media komunikasi yang lebih sering digunakan untuk menunjang komunikasi lisan yang menjangkau seluruh karyawan, lebih cepat dan tepat sasaran karena mudah dan terjangkau dengan kelebihan dapat diakses kapan saja dan dimana saja, yaitu internal website, email, majalah internal (Sinergi) dan buku pedoman perilaku Prinsip 46.

\section{Kerangka Teori}




\section{Teori Komunikasi Organisasi}

Komunikasi, sebagai suatu proses dengan mana orang-orang bermaksud memberikan pengertian-pengertian melalui pengiringan berita secara simbolis, dapat menghubungkan para anggota berbagai satuan organisasi yang berbeda dan bidang yang berbeda pula, sehingga sering disebut rantai pertukaran informasi. Konsep ini mempunyai unsur-unsur: 1) suatu kegiatan untuk membuat seseorang mengerti, 2) suatu sarana pengaliran informasi, dan 3) suatu sistem bagi terjalinnya komunikasi di antara individu-individu. Orang-orang bukan organisasi yang berkomunikasi, oleh karena itu suatu sistem komunikasi organisasi mencerminkan berbagai macam individu dengan latar belakang, pendidikan, kepercayaan, kebudayaan, keadaan jiwa, dan kebutuhan yang berbeda-beda (Handoko, 2013: 270-271). Korelasi antara ilmu komunikasi dengan organisasi terletak pada peninjauannya yang terfokus kepada manusia-manusia yang terlibat dalam mencapai tujuan organisasi itu. Ilmu komunikasi mempertanyakan bentuk komunikasi apa yang berlangsung dalam organisasi, metode dan teknik apa yang dipergunakan, media apa yang dipakai, bagaimana prosesnya, faktor-faktor apa yang menjadi penghambat, dan sebagainya (Ngalimun, 2017:83).

Komunikasi organisasi memiliki beberapa pengertian, diantaranya adalah: "Komunikasi organisasi adalah pengiriman dan penerimaan berbagai pesan organisasi di dalam kelompok formal maupun informal dari suatu organisasi (Wiryanto, 2005 dalam Ngalimun, 2017:84)".

"Komunikasi organisasi adalah perilaku pengorganisasian yang terjadi dan bagaimana mereka yang terlibat dalam proses itu bertransaksi dan memberi makna atas apa yang telah terjadi (Pace dan Faules, 2018:33).

Dari beberapa pengertian di atas dapat disimpulkan bahwa komunikasi organisasi adalah suatu proses penyampaian pesan dari organisasi kepada karyawan sebagai khalayak yang dilakukan baik secara formal maupun informal. Sifat terpenting komunikasi organisasi adalah penciptaan pesan, penafsiran, dan penanganan kegiatan anggota organisasi. Bagaimana komunikasi berlangsung dalam organisasi aan apa maknanya bergantung pada konsepsi seseorang menegnai organisasi (Pace dan Faules, 2018:34). Komunikasi juga penting untuk keberfungsian organisasi dalam kehidupan sehari-hari. Adalah melalui komunikasi para anggota organisasi: (1) mendefinisikan tujuan, (2) menggambarkan peran dan tanggun g jawab anggota, (3) mengoordinasikan pelaksanaan pekerjaan, (4) membentuk jaringan informasi, dan (5) mengembangkan budaya dan iklim organisasi, yang kesemuanya memandu perilaku organisasi (Ruben dan Stewart, 2013:325).

Menurut Handoko (2013:277), pemahaman yang lebih baik tentang komunikasi organisasi dapat diperoleh dengan mempelajari arah-arah dasar gerakannya yang tampak dengan terbentuknya saluran-saluran komunikasi. Saluran-saluran komunikasi formal ditentukan oleh struktur organisasi atau ditunjukkan oleh berbagai sarana formal lainnya. Sedangkan menurut Ngalimun (2017:84), komunikasi formal adalah komunikasi yang disetujui oleh organisasi 
itu sendiri dan sifatnya berorientasi kepentingan organisasi. Isinya berupa cara kerja di dalam organisasi, produktivitas, dan berbagai pekerjaan yang harus dilakukan dalam organisasi. Misalnya: memo, kebijakan, pernyataan, jumpa pers, dan surat-surat resmi. Ada pun komunikasi informal adalah komunikasi yang disetujui secara sosial. Orientasinya bukan pada organisasi, tetapi lebih kepada anggotanya secara individual. Terdapat dimensi-dimensi komunikasi dalam kehidupan organisasi:

\section{Komunikasi internal}

Komunikasi internal organisasi adalah proses penyampaian pesan antara anggota-anggota organisasi yang terjadi untuk kepentingan organisasi, seperti komunikasi antara pimpinan dengan bawahannya, antara sesama bawahan, dsb. Proses komunikasi internal ini bisa berwujud komunikasi antarpribadi ataupun komunikasi kelompok. Juga komunikasi ini bisa merupakan primer maupun sekunder (menggunakan media nirmassa). Komunikasi internal ini lazim dibedakan menjadi dua, yaitu:

a. Komunikasi vertikal, yaitu komunikasi dari atas ke bawah dari bawah ke atas. Komunikasi dari pimpinan kepada bawahan dan dari bawahan kepada pimpinan (Ngalimun, 2017:88). Menurut Ruben dan Stewart (2013:341342), secara umum, arus informasi yang telah diformalkan yang mengalir di dalam organisasi berhubungan erat dengan garis kewenangan. Pesan yang dikirim ke bawah secara umum melayani satu atau lebih fungsi-fungsi berikut ini:

1) Menetapkan tugas yang harus dilakukan

2) Memberikan instruksi tentang bagaimana melakukan tugas

3) Menyediakan informasi alasan mengapa tugas tertentu yang perlu dilakukan

4) Menyediakan informasi tentang kebijakan dan kegiatan organisasi

5) Menyediakan informasi tentang kinerja karyawan

6) Menyediakan informasi tentang organisasi dan misinya.

Komunikasi ke atas memiliki beberapa fungsi, ternasuk:

1) Memberikan masukan untuk pengambilan keputusan

2) Menasihati tentang informasi yang dibutuhkan supervisee

3) Menyediakan informasi berkenaan dengan penerimaan supervisees terhadap informasi, kepuasan, dan moralitas

4) Menampung dan menyalurkan keluhan dan pengaduan secara konstruktif

5) Membiarkan atasan untuk menilai efek komunikasi ke bawah yang dilakukan sebelumnya

6) Membantu bawahan mengatasi masalah dan menfasilitasi keterlibatan mereka

b. Komunikasi horizontal atau lateral, yaitu komunikasi antara sesama seperti dari karyawan kepada karyawan, manajer kepada manajer. Pesan dalam komunikasi ini bisa mengalir di bagian yang sama di dalam organisasi atau mengalir antar bagian. Komunikasi lateral ini memperlancar pertukaran pengetahuan, pengalaman, metode, dan masalah. Menurut Ruben dan Stewart (2013:342), fungsi berbagi informasi secara horizontal meliputi: 
1) Koordinasi perencanaan dan pelaksanaan tugas

2) Memberikan pemecahan masalah kolektif

3) Memfasilitasi perbedaan

4) Mengembangkan hubungan kerja yang supertif dan produktif

c. Komunikasi diagonal merupakan komunikasi yang memotong secara menyilang diagonal rantai perintah organisasi. Hal ini sering terjadi sebagai hasil hubungan-hubungan departemen lini dan staf. Hubungan-hubungan yang ada antara personalia lini dan staf dapat berbeda-beda, yang akan membentuk beberapa komunikasi diagonal yang berbeda-beda pula (Handoko, 2013:280).

2. Komunikasi eksternal

Komunikasi eksternal organisasi adalah komunikasi antara pimpinan organisasi dengan khalayak di luar organisasi. Komunikasi eksternal terdiri dari jlaur secara timbal balik (Ngalimun, 2017:89):

a. Komunikasi dari organisasi kepada khalayak. Komunikasi ini dilaksanakan umumnya bersifat informatif, yang dilakukan sedemikian rupa sehingga khalayak merasa memiliki keterlibatan, setidaknya hubungan batin. Komunikasi ini dapat melalui berbagai bentuk, seperti: majalah organisasi; prese release; artikel surat kabar atau majalah; pidato radio; film documenter; brosur; leaflet; poster; konferensi pers.

b. Komunikasi dari khalayak kepada organisasi. Komunikasi dari khalayak kepada organisasi merupakan umpan balik sebagai efek dari kegiatan dan komunitas yang dilakukan oleh organisasi.

\section{Kerangka Konseptual \\ Kampanye}

Pengertian secara umum tentang istilah kampanye yang dikenal sejak 1940-an campaign is generally exemply persuasioan in action (kampanye secara umum menampilkan suatu kegiatan yang bertitik tolak untuk membujuk), dan telah banyak dikemukan beberapa ilmuan, ahli dan praktisi komunikasi, yaitu definisinya sebagai berikut (Venus, 2004:7-29 dalam Ruslan, 2015:23):

a. Leslie B. Snyder (2002)

Secara garis besar bahwa kampanye komunikasi merupakan aktivitas komunikasi yang terorganisasi, secara langsung ditujukan khalayak tertentu, pada periode waktu yang telah ditetapkan untuk mencapai tujuan tertentu.

b. Pfau dan Parrot (1993)

Bahwa suatu kampanye yang secara sadar, menunjang dan meningkatkan proses pelaksanaan yang terencana pada periode tertentu untuk bertujuan mempengaruhi khalayak sasaran tertentu.

c. Roger dan Storey (1987)

Mendefinisikan kampanye sebagai serangkaian kegiatan komunikasi yang terorganisasi dengan tujuan untuk menciptakan dampak tertentu terhadap sebagian besar khalayak sasaran secara berkelanjutan dalam periode waktu tertentu.

d. Rajasundaram (1981) 
Suatu kampanye merupakan koordinasi dari berbagai perbedaan metode komunikasi yang memfokuskan perhatian pada permasalahan tertentu dan sekaligus cara pemecahannya dalam kurun waktu tertentu.

Pemaparan dari berbagai definisi para pakar mengenai arti kampanye tersebut di atas maka dapat ditarik suatu kesimpulan, yaitu terdapat kegiatan-kegiatan; 1) Adanya aktivitas proses komunikasi kampanye untuk mempengaruhi khalayak tertentu, 2) Untuk membujuk dan memotivasi khalayak untuk berpartisipatif, 3) Ingin menciptakan efek atau dampak tertentu seperti yang direncanakan, 4) Dilaksanakan dengan tema spesifik dan nara sumber jelas, 5) Dalam waktu tertentu atau telah ditetapkan, dilaksanakan secara terorganisasi dan terencana baik untuk kepentingan kedua belah pihak atau sepihak (Ruslan, 2015:24).

Aktivitas komunikasi dalam berkampanye biasanya berkaitan dengan suatu kepentingan dan tujuannya apa, siapa khalayak sasarannya, dalam rangka kegiatan apa, untuk membujuk atau memotivasi khalayak. Dalam berbagai kegiatan tersebut terdapat beberapa jenis program kampanye yang dilaksanakan secara prinsip merupakan kegiatan bertitik tolak untuk memotivasi atau membujuk, dan mencapai tujuan tertentu, maka menurut Charles U. Larson dalam Ruslan (2015:25) jenis-jenis kampanye sebagai berikut:

\section{Product-Oriented Campaigns}

Kegiatan dalam berkampanye berorientasi pada produk, dan biasanya dilakukan dalam kegiatan komersil kampanye promosi pemasaran suatu peluncuran produk yang baru. Sedangkan kampanye PR bertujuan untuk Membangun citra positif perusahaan melalui program kepedulian dan tanggung jawab sosial.

2. Candidate-Oriented Campaigns

Kegiatan kampanye yang berorientasi bagi calon (kandidat) untuk kepentingan kampanye politik.

3. Ideological or Cause-Oriented Campaigns

Jenis kampanye ini berorientasi yang bertujuan bersifat khusus dan berdimensi perubahan sosial (social change campaings).

Dalam kampanye public relations, yang menjadi khalayak sasarannya (target audience) secara umum dikelompokkan sebagai berikut:

1. Kelompok yang berkepentingan, seperti pemerintah (government relations)

2. Masyarakat sekitar atau tertentu (community relations)

3. Kelompok pemakai produk atau pelanggan (customer and consumen relations).

4. Badan lembaga swadaya masyarakat (consumen bodies).

5. Kelompok sebagai penekan (pressure group).

6. Kelompok pemuka agama dan masyarakat (opinion leader)

7. Trade association atau asosiasi perdagangan dan profesi

8. Kelompok business relatios atau kelompok relasi bisnis.

9. Kelompok internal (internal relations), seperti employee relations, antar manajemen, jajaran pimpinan, dan pemilik perusahaan (stock holder)

Menurut Venus (2018:139), terdapat beragam saluran yang digunakan dalam kegiatan kampanye. Secara umum, saluran kampanye yang ada dapat dikelompokkan ke dalam saluran langsung (nonmediated) dan saluran bermedia (mediated). Saluran langsung, misalnya: kunjungan lapangan (blusukan), 
penyuluhan, dialog publik, dan penyelenggaraan event. Sementara saluran tidak langsung umumnya meliputi media umum (selebaran, newsletter, poster, banner, spanduk), saluran media massa (televisi, radio, majalah, surat kabar, dan film bioskop), serta saluran media sosial (facebook, twitter, youtube, line, dan instagram). Dalam Ruslan (2015:35) terdapat tiga macam kelompok publik yang memberikan respon terhadap pesan yang disampaikan oleh komunikator dalam melaksanakan kampanye, yaitu sebagai berikut:

1. Kelompok penentang atau oposan (opponents), biasanya pesan yang disampaikanitu selalu ditanggapi negative. Apalagi kalau oposan tersebut memiliki nama cukup beken (public figure) yang sangat besar pengaruhnya di mata public dan pihak pers dalam membentuk opini.

2. Kelompok yang memihak atau proposan (proponets), pada kelompok ini bagi seorang komunikator tidak ada masalah untuk menghadapinya karena berpotensi sebagai pendukung.

3. Kelompok yang tidak peduli (uncommitted), dalam kelompok ini bagi seorang public relations agak susah-susah gampang untuk mengendalikan opini atau ingin memperoleh tanggapan yang bersangkutan.

Peristiwa dalam proses komunikasi kampanye ini melibatkan konseptor (coneption skill), teknisi komunikasi (technical skill), dan komunikator dengan segala kemampuan komunikasi (communication skill) untuk mempengaruhi komunikan dengan berbagai aspek teknis dan praktis operasional dalam bentuk perencanaan yang taktis dan strategik untuk mencapai tujuan tertentu.

Untuk mecapai keberhasilan dalam melaksanakan penggiatan program kampanye PR, maka tentukan:

1. Tujuan yang hendak dicapai

2. Sasaran kampanye

3. Ruang lingkup kampanye

4. Jangka waktunya

5. Publik sasarannya

6. Tema, topik atau isu dari kampanye tersebut

7. Efek yang akan diinginkan dalam suatu kampanye

8. Fasilitas, perlengkapan, atau sarana yang akan menunjang suatu kampanye

9. Pembentukan team work yang solid dan professional.

Kegiatan proses perencanaan program kampanye yang dilaksanakan oleh Public Relations harus terkoordinasi, memiliki sasaran jelas dalam rancangan program untuk mencapai tujuan yang spesifik dan memiliki dukungan seperangkat interelasi berbagai kepentingan yang berkaitan dengan pencapaian tujuan utama suatu organisasi dalam waktu perpanjangan (tujuan strategis) atau pendek (taktik pelaksanaannya) yang disesuaikan dengan maksud pernyataan misi perusahan. Kemudian penjelasan penerapannya melalui program The Public Relation Campaigns Organization Model adalah sebagai berikut:

1. Campaigns Model of Succesful Organization (Model Kampanye Organisasi yang Sukses)

1. Mendefinisikan misi atau pernyataan nilai-nilai yang diinginkan oleh perusahaan.

2. Budaya perusahaan 
1) Mengkomunikasikan nilai-nilai budaya perusahaan yang mampu menampilkan message tertentu dengan cerita kesuksesan perusahaan melalui media komunikasi, kampanye iklan promosi korporat, publikasi, dan pemberitaan bernilai positif disiarkan ke berbagai media massa sebagai upaya menciptakan citra dengan menampilkan reputasi perusahaan secara baik.

2) Menampilkan kemampuan pelayanan dan kinerja tim kerja professional yang mengacu pada nilai-nilai budaya organisasi bersangkutan dengan memiliki komitmen dan tanggung jawab yang tinggi, tata kelola bisnis yang etis, tingkat kemampuan produktivitas karyawan yang berkualitas tinggi, dan hingga perusahaan memberikan pelayanan yang prima bagi pihak pelanggannya

3. Membangun hubungan public yang positif

4. Reputasi perusahaan

2. Positioning Statement (Pernyataan Posisi)
a. Public Awareness
b. Offer information
c. Public Education
d. Reinforce the attitudes and behavior
e. Behaviour modification

\section{Budaya Organisasi}

Budaya adalah satu set nilai, penuntun kepercayaan akan suatu hal, pengertian dan cara berpikir yang dipertemukan oleh para anggota organisasi dan diterima oleh anggota baru seutuhnya. Tujuan budaya adalah melengkapi para anggota dengan rasa identitas organisasi dan menimbulkan komitmen terhadap nilai-nilai yang dianut organisasi (Kasali, 2016:109-110). Menurut Littlejhon dan Foss (2011: 383), budaya organisasi adalah sesuatu yang dihasilkan melalui interaksi sehari-hari dalam organisasi bukan hanya tugas pekerjaan, tetapi semua jenis komunikasi. Sedangkan menurut Rubben \& Stewart (2013:346), budaya organisasi adalah keseluruhan dari simbol, peristiwa, tradisi, standarisasi pola perilaku verbal dan non verbal, cerita rakyat, aturan, dan ritual yang memberi organisasi ciri-ciri atau kepribadian. Budaya organisasi tumbuh dari kegiatan para anggota. Meskipun budaya organisasi merupakan produk komunikasi manusia, ia dapat mencapai kualitas yang objektif dan memaksa kepada individu-individu di dalam organisasi (Rubben \& Stewart, 2013:347). Budaya organisasi memainkan sentral dan meresap di dalam segala dinamika organisasi, dan mereka melayani banyak fungsi penting komunikasi bagi mereka yang membuat dan berpartisipasi dalam organsiasi. Fungsi-fungsi itu meliputi (Rubben \& Stewart, 2013:348-349):

1. Memberikan orang yang ada di dalam organisasi merasa memiliki identitas individual dan identitas kolektif.

2. Berkontribusi untuk pengembangan struktur dan kontrol.

3. Membantu anggota berkenalan dengan kebiasaan dan tradisi organisasi.

4. Memupuk keterpaduan di antara anggota organisasi. 
Budaya adalah sebuah proses (throughput). Sebuah proses perubahan dari kondisi yang satu (input) ke kondisi selanjutnya (output) atau sebuah proses pengubahan seperangkat input menjadi output yang sesuai visi dan misi atau tujuan organisasi. Dari pemakaian, penikmatan, atau pelaksanaan output diperoleh outcome diperoleh bahan untuk dijadikan feedback, demikian seterusnya. Rangkaian itu menunjukkan lingkungan (1) sebagai sumber input (2), proses perubahan input mnejadi output (4) yang disebut throught (3), penggunaan output (6), hasil penggunaan output yaitu outcome (7), evaluasi oleh consumer (8), dan hasil evaluasi dijadikan feedback (9). Dilihat dari sudut kelembagaan, dalam proses siklik itu terlibat berbagai pihak yang subkuklturnya berbeda satu dengan lainnya (Ndraha, 2015:80).

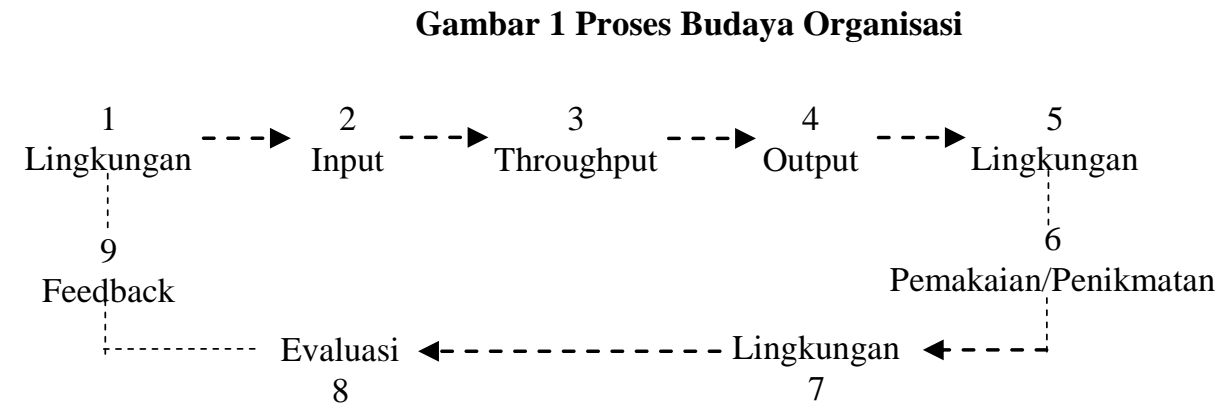

Menurut Ndraha (2015:127), yang dimaksud dengan proses budaya adalah pertama, proses terbentuknya suatu Budaya Sebagai Output (BSO) dari suatu Budaya Sebagai Input (BSI) melalui proses yang berjalan dengan sendirinya tanpa intervensi sengaja oleh organisasi, dan kedua, proses pembentukan budaya, dari BSI menjadi BSO, di dalam suatu organisasi atau perusahaan, melalui (intervensi) manajemen. Dilihat dari sudut BSO sebagai produk, proses itu berbentuk siklus, tetapi dilihat dari sudut organisasi, berbentuk fungsi. Proses itu terdiri dari sejumlah subproses, rute-rute, atau tahapan-tahapan, ada yang kumulatif dan ada yang alternative, jalin-menjalin, antara lain kontak nilai, penggalian nilai, seleksi nilai, pelembagaan nilai, sosialisasi budaya, aktulisasi budaya, kontrol budaya, evaluasi budaya, pertahanan budaya, perubahan budaya, dan pewaris budaya, yang terjadi dalam hubungan antara suatu organisasi dengan lingkungannya secara berkesinambungan. Proses budaya terdiri dari sejumlah rute atau mata rantai, sebagai berikut:

1. Kontak nilai

2. Penggalian dan revitalisasi nilai

3. Seleksi nilai

4. Pelembagaan nilai

5. Terbentuknya atau pembentukan budaya

6. Komunikasi budaya

7. Kontrol budaya

8. Pertahanan budaya

9. Konflik budaya

10. Perubahan atau pengubahan budaya

11. Pewarisan budaya 
Perubahan budaya dapat diamati sebagai gejala sosial dan menjadi sasaran sosiologi dan antropologi, tetapi pengubahan budaya sebagai program pembangunan merupakan sasaran utama budaya organisasi. Perubahan budaya jauh lebih sukar ketimbang pembentukan budaya. Diperlukan gerakan, reformasi, revolusi jika diperlukan. Menurut Graves (1986) dalam Ndraha (2015:153), terdapat perubahan budaya pada tiga level, pertama pada level perilaku, kedua pada sikap, dan ketiga pada nilai.

\section{Gambar 2 Model Perubahan Budaya}

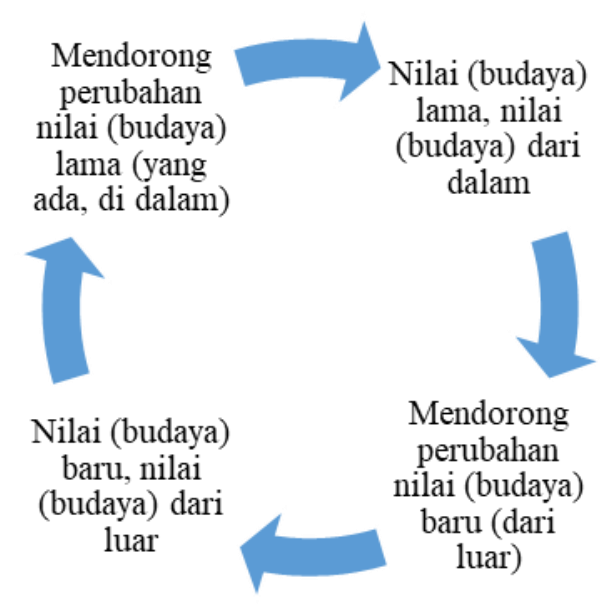

Menurut Wasesa dan Macnamara (2016:128), salah satu fungsi internal public relations adalah membantu terciptanya budaya perusahaan yang sesuai visi organisasi dan menurut Kasali (2016: 110), seorang praktisi PR turut mengemban misi untuk mengembangkan dan memelihara budaya perusahaan. Budaya perusahaan pada sisi yang sama merupakan penerapan nilai-nilai dalam suatu masyarakat yang terikat bekerja di bawah naungan suatu perusahaan. Budaya perusahaan pada umumnya terdiri atas dua lapisan. Lapisan pertama adalah lapisan yang umumnya mudah dilihat dan sering dianggap mewakili budaya perusahaan secara menyeluruh. Lapisan pertama ini disebut Visible Artifacts. Lapisan ini terdiri atas cara orang berperilaku, berbicara dan berdandan. Termasuk simbol-simbol yang dipakai, kegiatan protokoler (seremonial), dan cerita-cerita yang sering dibicarakan oleh para anggota. Visible Artifacts hadir mewakili nilainilai yang lebih dalam dari para anggota. Lapisan ke dua yang lebih dalam itulah yang sesungguhnya disebut budaya. Ini terdiri atas nilai-nilai pokok, filosofi, asumsi, kepercayaan, dan proses berpikir dalam perusahaan. Untuk mengartikan budaya perusahaan, seorang praktisi PR dapat melakukan analisis yang dimulai dari Visible Artifacts, kemudian melakukan penelusuran terhadap pidato pendiri, wawancara yang dimuat di media massa, kejadian penting yang menyebabkan perusahaan harus mengambil tindakan drastis, sejarah perusahaan, dan mission statement perusahaan. 


\section{METODE PENELITIAN}

Pada penelitian ini peneliti menggunakan paradigma konstruksivisme. Tujuan penelitian ini adalah untuk memahami dan merekonstruksi berbagai konstruksi yang sebelumnya dipegang orang yang berusaha ke arah konsesus, namun masih terbuka bagi interpretasi baru seiring dengan perkembangan informasi dan kecanggihan. Penelitian ini bersifat deskriptif kualitatif, penelitian kualitatif bertujuan untuk mendapatkan pemahaman yang sifatnya umum terhadap kenyataan sosial dari perspektif partisipan (Ruslan, 2006:212). Pemahaman tersebut tidak ditentukan terlebih dahulu, tetapi diperoleh setelah melakukan analisis terhadap kenyataan sosial yang menjadi fokus penelitian, dan kemudian ditarik suatu kesimpulan berupa pehaman umum tentang kenyataan tersebut.

Metode penelitian yang digunakan untuk menjawab bagaimana proses kampanye perubahan budaya organisasi PT Kazero Putra Perkasa. Pengumpulan data dan informasi yang dibutuhkan untuk mendukung penelitian ini, melalui data primer dengan teknik observasi dan studi dikumen dalam pengumpulanpengumpulan data. Kemudian melalui data sekunder, dimana peneliti melakukan studi pustaka sebagai kegiatan untuk menghimpun informasi yang relevan dengan topik atau masalah yang menjadi obyek penelitian. Informasi tersebut dapat diperoleh dari buku-buku, karya ilmiah, tesis, disertasi, ensiklopedia, internet, dan sumber-sumber lain.

Analisis data dalam penelitian kualitatif dilakukan pada saat pengumpulan data berlangsung, dan setelah selesai pengumpulan data dalam periode tertentu. Selain itu, analisis data berlangsung bersamaan dengan proses pengumpulan data melalui 3 tahapan yang dilakukan secara simultan yaitu reduksi data, penyajian data dan verifikasi data (pengambilan kesimpulan).

\section{HASIL PENELITIAN DAN PEMBAHASAN}

PT Kazeto Putra Perkasa merupakan salah satu perusahaan yang bergerak di bidang jasa pendidikan yang telah berdiri sejak 2012. Dalam perjalanannya hingga saat ini telah mengalami perubahan struktur organisasi lebih dari 5 kali sebagai dampak atas tantangan zaman dan persaingan bisnis. Selain itu sebagai upaya menghadapi era Industri 4.0, PT Kazeto Putra Perkasa membuat kebijakan atas penyesuaian strategi perusahaan dari visi, misi, tujuan, sasaran, hingga budaya organisasinya. Selama 7 tahun terakhir budaya organisasi 7 nilai telah dianut oleh karyawan, namun belum memberikan progres yang baik. Hal ini terlihat dari data yang didapatkan dari bagian marketing, bahwa jumlah pelanggan dimana terjadi penurunan jumlah Pelanggan dari 602 pelanggan di tahun 2012 kemudian menurun menjadi 577 pelanggan di tahun 2018. Sebagai upaya memperbaiki kondisi yang terjadi, maka pimpinan sepakat untuk mengubah budaya organisasi untuk meningkatkan kinerja perusahaan yang dikenal dengan 7 Nilai menjadi 4 Tata Nilai Kerja. 
Tabel 1. Perubahan Budaya Organisasi

\begin{tabular}{|c|l|l|l|}
\hline \multirow{2}{*}{ No } & \multicolumn{2}{|c|}{ 7 Nilai } & \multicolumn{2}{c|}{ 4 Tata Nilai Kerja } \\
\cline { 3 - 4 } & & Kompetensi Inti & Budaya Kerja \\
\hline 1 & Integritas & Integrity & Efektif \\
\hline 2 & Profesional & Smart & Efisien \\
\hline 3 & Keteladanan & Speed & Inovatif \\
\hline 4 & Kekeluargaan & Service Excellent & Terintergrasi \\
\hline 5 & Kemashalatan & & \\
\hline 6 & Kepuasan Pelanggan & & \\
\hline 7 & Penghargaan SDM & & \\
\hline
\end{tabular}

Sumber: PT Kazeto Putra Perkasa

Adapun untuk mengkomunikasikan perubahan budaya organisai tersbeut digunakan strategi kampanye dengan jenis kampanye Ideological or CauseOriented Campaigns yang bertujuan bersifat khusus dan berdimensi perubahan sosial (social change campaings) dari budaya lama ke budaya baru. Peristiwa dalam proses komunikasi kampanye ini melibatkan konseptor (conception skill), teknisi komunikasi (technical skill), dan komunikator dengan segala kemampuan komunikasi (communication skill) yang dilakukan oleh direktur dan wakil dirketur bidang umum untuk mempengaruhi karyawan untuk mencapai tujuan PT Kazeto Putra Perkasa. Tipe kampanye yang digunakan, yaitu Campaigns Model of Succesful Organization (Model Kampanye Organisasi yang Sukses):

1. Mendefinisikan misi atau pernyataan nilai-nilai yang diinginkan oleh perusahaan.

Visi:

Menjadi perusahaan yang unggul dan profesional dengan senantiasa berinovasi dalam penyelenggaraan jasa dan konsultan di bidang pendidikan serta penyedia sarana prasarana, sehingga memiliki keberlangsungan perusahaan yang bermanfaat bagi bangsa dan negara Indonesia.

Misi:

1. Menyediakan pelayanan jasa pendidikan dan konsultasi yang berkualitas dengan biaya kompetitif.

2. Membangun manajemen dengan budaya organisasi yang unggul (efektif, efisien, inovatif, dan terintegrasi) serta profesional.

3. Memberikan kontribusi sosial (CSR) dan mengedukasi masyarakat untuk peduli serta terlibat aktif dalam membangun bangsa dan Negara Indonesia.

2. Mengkomunikasikan nilai-nilai budaya perusahaan yang mampu menampilkan meningkatkan kinerja karyawan dan pelayanan konsumen.

Tabel 2. Budaya Organisasi PT Kazeto Putra Perkasa Tahun 2019

\begin{tabular}{|l|l|l|}
\hline No & \multicolumn{1}{|c|}{ Kompetensi Inti } & \multicolumn{1}{|c|}{ Budaya Kerja } \\
\hline 1 & Integrity mampu bertindak secara & Karyawan mampu bekerja dengan \\
& $\begin{array}{l}\text { Karyawan man } \\
\text { konsisten dan utuh dalam perkataan dan } \\
\text { perbuatan, sesuai dengan nilai-nilai dan } \\
\text { prinsip perusahaan, seperti: menjunjung } \\
\text { tinggi kejujuran, beretika, berkomitmen, } \\
\text { (secepat mungkin) dalam mencapai tujuan } \\
\text { kerjang dengan hasil yang sesuai. }\end{array}$ \\
\hline 2 & Smart & Efisien \\
\cline { 2 - 3 } & Karyawan memiliki usaha tambahan/lebih & Karyawan bekerja untuk menghasilkan \\
\hline
\end{tabular}




\begin{tabular}{|c|c|c|}
\hline & $\begin{array}{l}\text { yang dikeluarkan untuk mengumpulkan } \\
\text { informasi yang lebih banyak sehubungan } \\
\text { dengan pelaksanaan pekerjaan dan } \\
\text { pengambilan keputusan. }\end{array}$ & $\begin{array}{l}\text { output kerja dengan memanfaatkan input } \\
\text { (sumber daya) serendah mungkin. }\end{array}$ \\
\hline \multirow[t]{2}{*}{3} & Speed & Inovatif \\
\hline & $\begin{array}{l}\text { Karyawan memiliki dorongan dalam } \\
\text { bertindak untuk melebihi yang dibutuhkan } \\
\text { atau yang dituntut oleh } \\
\text { pekerjaan/lingkungan tanpa menunggu } \\
\text { perintah lebih dahulu dan dilakukan untuk } \\
\text { memperbaiki atau meningkatkan hasil } \\
\text { pekerjaan atau menghindari timbulnya } \\
\text { masalah atau menciptakan peluang baru. }\end{array}$ & $\begin{array}{l}\text { Karyawan berupaya melakukan perbaikan, } \\
\text { menyajikan sesuatu yang baru/berbeda } \\
\text { dengan yang sudah, baik dalam bentuk } \\
\text { produk maupun cara kerja. }\end{array}$ \\
\hline \multirow[t]{2}{*}{4} & Service Excellent & Terintegrasi \\
\hline & $\begin{array}{l}\text { Karyawan memiliki keinginan untuk } \\
\text { membantu atau melayani pelanggan/rekan } \\
\text { kerja. }\end{array}$ & $\begin{array}{l}\text { Karyawan bekerja secara terpadu dengan } \\
\text { berbagai pihak dalam mencapai tujuan } \\
\text { kerja yang optimal. }\end{array}$ \\
\hline
\end{tabular}

Sumber : SK Nomor: 005/PTKPP-SK/DIR/I/2019

3. Membangun hubungan public yang positif

Seluruh karyawan dihimbau untuk meningkatkan pelayanan baik kepada konsumen maupun rekan sekerja dengan meningkatkan kompetensi service excellent dengan harapan konsumen dapat terpuaskan dan dapat mereferensikan ke rekan-rekannya untuk menggunakan produk perusahan.

Gambar 3. Kegiatan Memberikan kepada pelayanan kepada klien (orangtua/wali dan siswa)
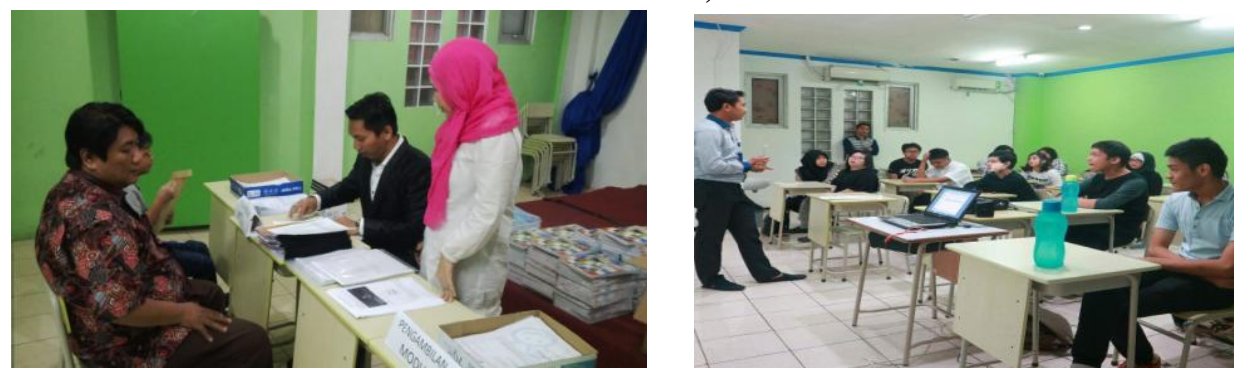

Sumber: Bagian Pendidikan "HOMESCHOOLING KAK SETO”

4. Reputasi perusahaan

PT Kazeto Putra Perkasa dengan brand produk "HOMESCHOOLING KAK SETO" telah menjadi pionerr pertama pendidikan berbasis homeschooling selama selama 12 tahun dan telah dikunjungi oleh Menteri Pendidikan dan Kebudayaan. Dengan personal branding "Kak Seto" menjadikan seluruh karyawan perlu menjaga reputasi perusahaan dan Kak Seto sebagai upaya mempertahankan eksistensi di dunia pendidika non formal. 


\section{Gambar 4. Kunjungan Menteri Pendidikan dan Kebudayaan}
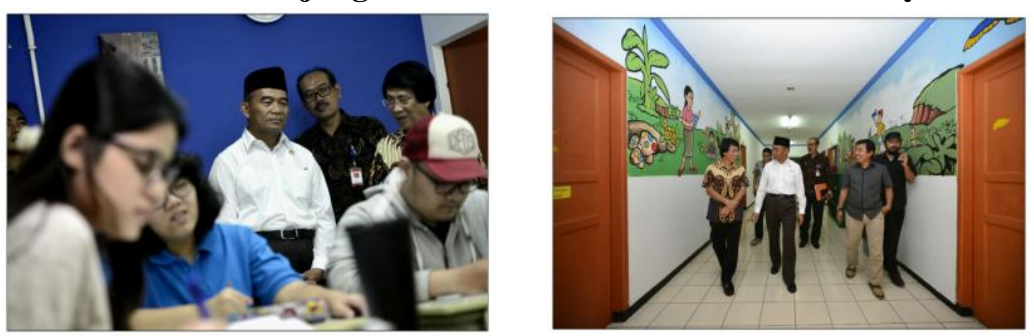

Sumber: Dept. Network \& Marketing PT KAzeto Putra Perkasa

Untuk mecapai keberhasilan dalam melaksanakan penggiatan program kampanye, maka tentukan:

1. Tujuan yang hendak dicapai

PT Kazeto Putra Perkasa memiliki tujuan menjadikan karyawan mampu menerima perubahan dalam organisasi dan meningkatkan kinerja sehariharinya, sehingga perusahaan dapat mencapai tujuannya.

2. Sasaran kampanye

Dalam kampanye perubahan budaya organisasi ini yang menjadi sasaran adalah seluruh karyawan yang berjumlah 155 orang dari level staf hingga manajer.

3. Ruang lingkup kampanye

Dikarenakan sasaran kampanye perubahan budaya organisasi ini ditujukan kepada pihak internal, yaitu seluruh karyawan PT Kazeto Putra Perkasa maka ruang lingkupnya terbatas di dalam perusahaan saja.

4. Jangka waktunya

Proses kampanye perubahan budaya organisasi ini dibagi menjadi 2 tahap di tahun 2019. Dimana tahap pertama dilakukan dari Januari-Juni 2019 dan tahap kedua dilakukan Agustus-Desember 2019 nanti.

5. Publik sasarannya

Yang menjadi public sasasaran dari PT Kazeto Putra Perkasa adalah konsumen yang telah menggunakan produk perusahaan dan masyarakat/calon konsumen yang belum menggunakan produk perusahaan.

6. Tema, topik atau isu dari kampanye tersebut

Isu yang dimunculkan adalah jumlah dan pelayanan konsumen yang menurun, serta kinerja karyawan yang belum terintegrasi. Tema yang diangkat dalam kampanye ini kebijakan PT Kazeto Putra Perkasa Gemilang 2020.

7. Efek yang diharapkan dalam kampanye perubahan budaya organisasi

Karyawan dapat meningkatkan semangat kerja (produktifitas kinerja) dan mampu memberikan pelayanan yang prima kepada konsumen.

8. Fasilitas, perlengkapan, atau sarana yang akan menunjang suatu kampanye Kampanye perubahan budaya organisasi dilakukan melalui beberapa event perusahaan, sehingga membutuhkan perlengkapan pendukung, seperti 
ruangan kapasitas besar, pengeras suara, proyektor, laptop, dan perlengkapan lainnya.

9. Pembentukan team work yang solid dan profesional.

Untuk mensukseskan proses kampanye perubahan budaya organisasi ini, maka PT Kazeto Putra Perkasa membagi dua tim, yaitu departemen SDM dan Departemen Nerwork \& Marketing.

Awal tahun 2019 menjadi tahun yang menengangkan bagi PT Kazeto Putra Perkasa, dimana akan menyambut PT Kazeto Putra Perkasa Gemilang 2020 yang sudah direncanakan 5 tahun lalu. Akan tetapi tantangan yang dihadapi saat ini adalah perubahan organisasi yang datang dari eksternal, yaitu perkembangan teknologi yang melahirkan era industry 4.0. Selain itu dari faktor internal muncul penurunan jumlah konsumen dan sikap/perilaku kerja yang kurang optimal. Untuk itu pemimpin PT Kazeto Putra Perkasa bersepakat untuk membuat kebijakan perubahan visi, misi, dan budaya perusahaan. Agar seluruh karyawan dapat mengetahui dan memahami budaya organisasi yang baru, maka dilakukan kampanye perubahan budaya organsiasi. Perubahan tersebut memiliki maksud agar PT Kazeto Putra Perkasa dapat meraih tujuannya pada tabel 3.

Tabel 3. Tujuan PT Kazeto Putra Perkasa

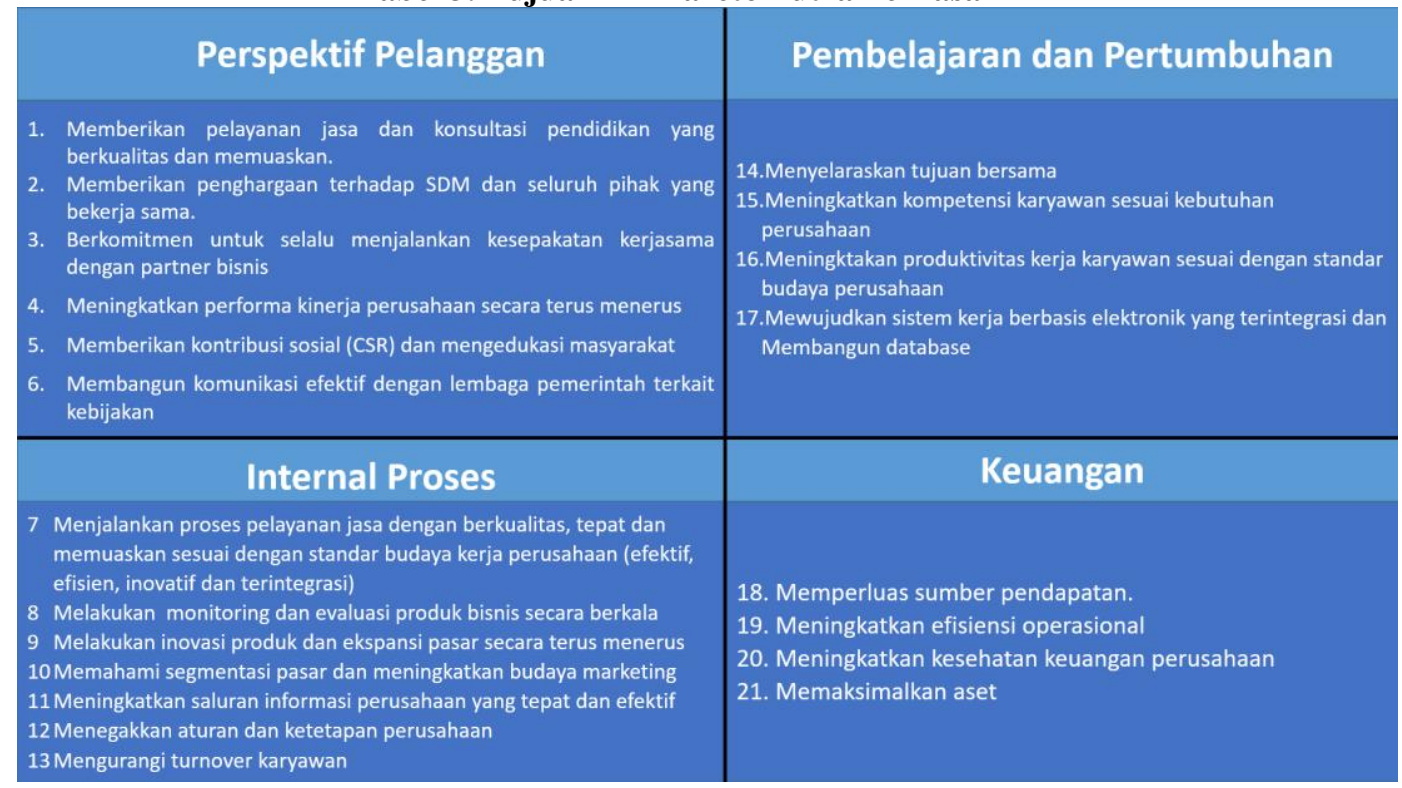

Sumber: PT Kazeto Putra Perkasa

Dalam kampanye perubahan budaya organsiasi ini yang menjadi sasaran adalah seluruh karyawan PT Kazeto Putra Perkasa dari level staff hingga manajer. Adapun ruang lingkup kampanye ini hanya sebatas internal perusahan. Proses kampanye ini memiliki jangka waktu 1 tahun yang dibagi menjadi 2 tahap, yaitu: tahap pertama dimulai bulan Januari hingga Juni 2019 yang telah dilakukan dan tahap kedua akan dilakukan bulan Agustus hingga Desember 2019. Kampanye perubahan budaya organisasi ini tidak terlepas dari public sasarannya yang dituju, yaitu konsumen yang telah menggunakan produk perusahaan atau yang akan 
menggunakan (konsumen baru). Tema/topikyang diangkat adalah arah kebijakan PT Kazeto Putra Perkasa hingga tahun 2020 yang dijabarkan dari visi, misi, tujuan, sasaran, program kerja, dan tata nilai kerja. Isu terhangat pun ikut diangkat, seperti perkembangan teknologi menuntut karyawan memiliki kompetensi di era industri 4.0, dibutuhkan kemampuan agile dalam beradaptasi dan fleksibel menghadapi perubahan yang begitu cepat. Hingga akhirnya tata nilai kerja yang akan diterapkan mulai tahun 2019 ini, yaitu: Integrity, Speed, Smart, Service Excellent (Komptensi inti) dan Efektif, Efisiensi, Inovatif, dan Terintegrasi (Budaya Kerja).

Gambar 5. Materi/Topik/Isu yang dikomunikasikan
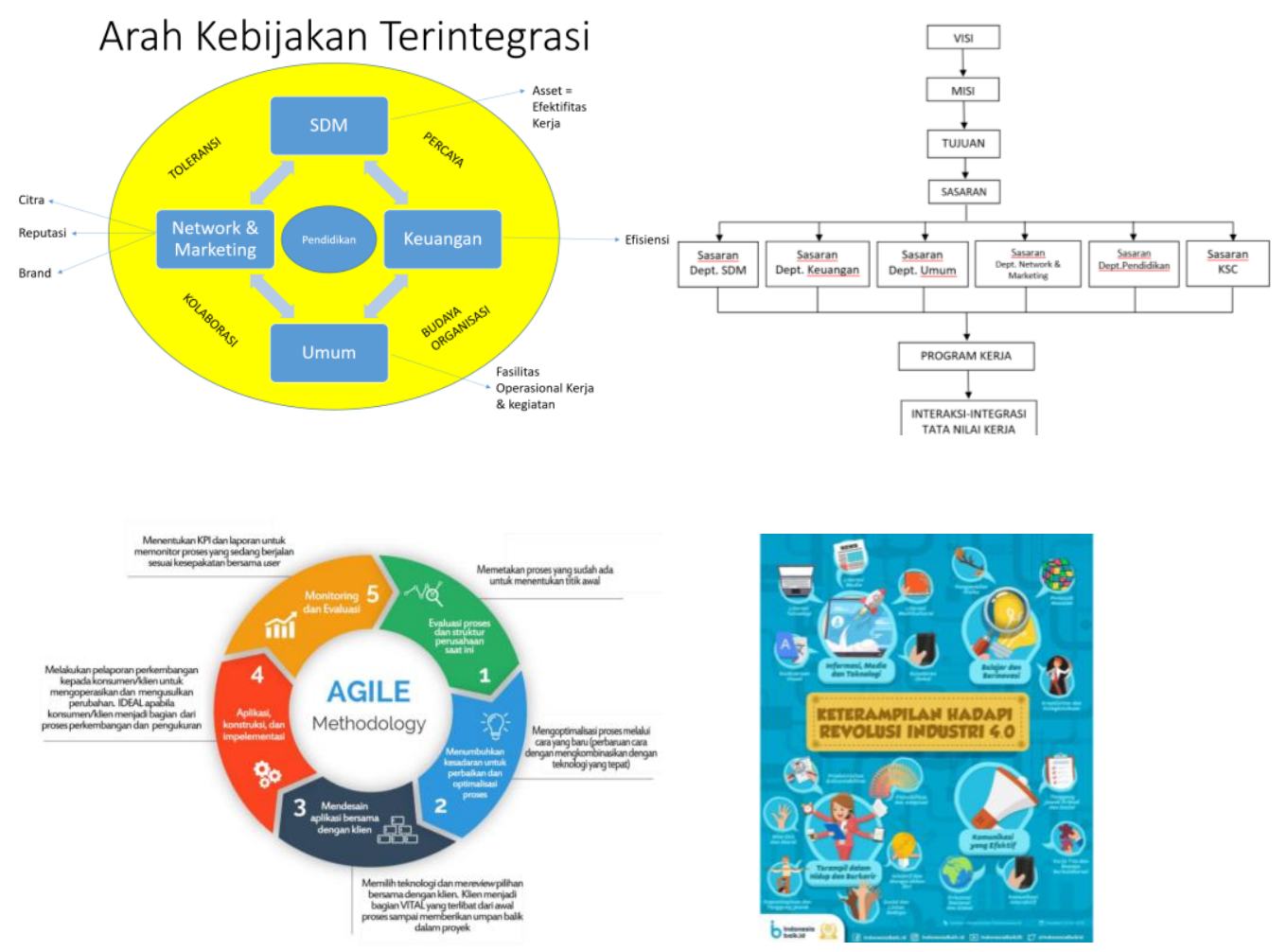

\section{CORE COMPETENCY}

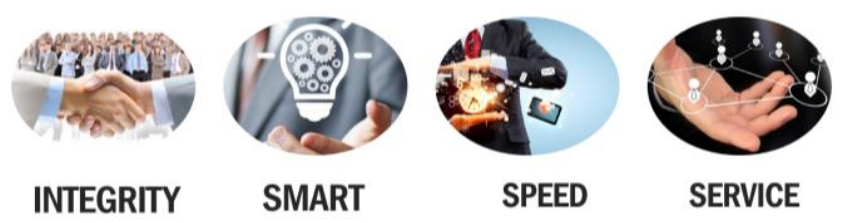

Sumber: Direktur dan Wakil Direktur bidang Umum

Dari kampanye perubahan budaya organisasi ini menghasilkan efek bagi karyawan, yaitu telah mengetahui dan memahami budaya perusahaan terbaru dan apa yang hendak dicapai oleh perusahaan tahun 2020 nanti yang disebut PT 
Kazeto Putra Perkasa Gemilang. Semangat kerja baru pun muncul dalam diri karyawan, hal ini ditunjukkan dari data kehadiran karyawan yang sangat tinggi selama periode Januari-Juni 2019 berikut ini:

\section{Gambar 6. Data Absensi Karyawan}

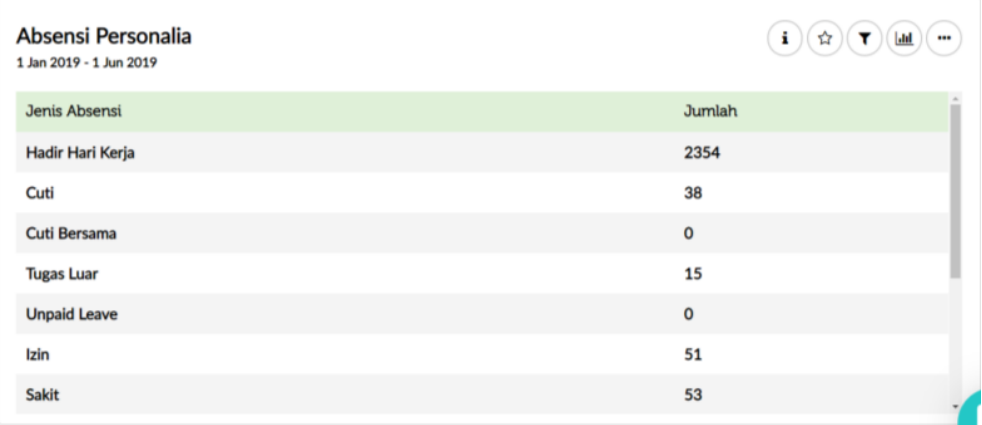

Sumber: Dept. SDM PT Kazeto Putra Perkasa

Kampanye perubahan budaya organisasi ini dilakukan melalui event-event perusahaan, seperti: lomba memasak saat memperingati Hari Kartini, nonton bareng "The Avenger End Game", buka bersama, dan halal bi halal karyawan. Disela-sela kegiatan tersebut disampaikan pesan-pesan terkait perubahan budaya organisasi yang baru untuk menghadapi era industri 4.0.

\section{Gambar 7. Event-event Kampanye Perubahan Budaya Organsiasi}
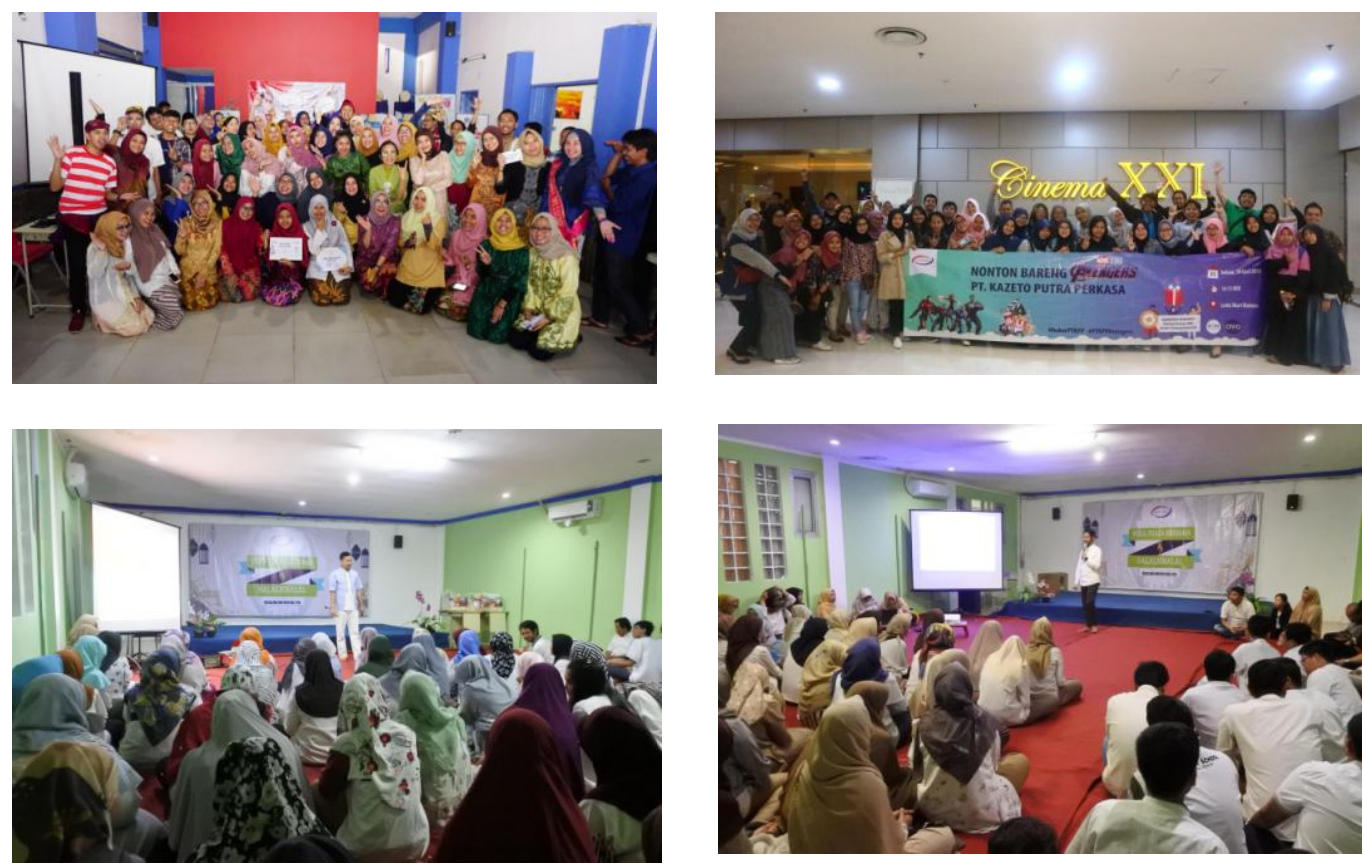

Sumber: Dept. SDM PT Kazeto Putra Perkasa 
Dalam pelaksanaan kampanye perubahan budaya organisasi ini, PT Kazeto Putra Perkasa memberikan tugas kepada Departemen SDM untuk menyusun dan melaksanakan event-event perusahaan, serta Departemen Network \& Marketing yang membawahi staf Public Relations bertugas membuat pesan-pesan non verbal dan disebarkan melalui jaringan komunikasi grup whatsapp dan media lainnya. Yang menjadi key person sebagai komunikator adalah direktur dan wakil direktur bidang Umum, karena merekalah yang merumuskan arah kebijakan perubahan budaya organisasi tersebut.

Gambar 8. Pesan Non Verbal Kampanye Budaya Organisasi

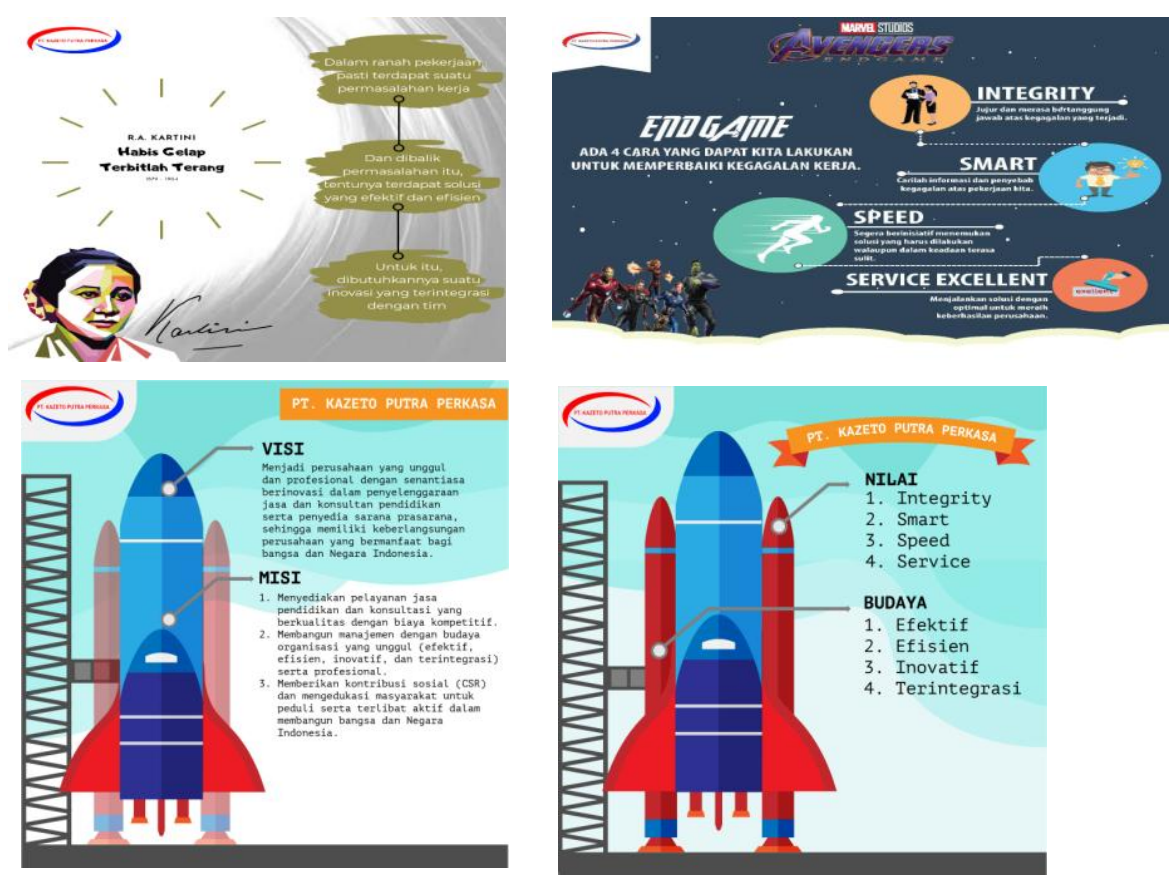

Sumber: Dept. Network \& Marketing PT Kazeto Putra Perkasa

\section{KESIMPULAN}

1. PT Kazeto Putra Perkasa melaksanakan kampanye perubahan budaya organisasi dengan jenis kampanye Ideological or Cause- Oriented Campaigns yang bertujuan bersifat khusus dan berdimensi perubahan sosial (social change campaings) dari budaya lama ke budaya baru. Dimana tipe kampanye yang digunakan, yaitu Campaigns Model of Succesful Organization (Model Kampanye Organisasi yang Sukses) dengan mendefinisikan misi atau pernyataan nilai-nilai yang diinginkan oleh perusahaan, mengkomunikasikan budaya nilai-nilai perusahaan, membangun hubungan public yang positif, dan reputasi perusahaan.

2. Untuk mengkampanyekan perubahan budaya organisasi PT Kazeto Putra Perkasa dari 7 nilai: Integritas, Profesional, Keteladanan, Kekeluargaan, Kemashalatan, Kepuasan Pelanggan, dan Penghargaan SDM menjadi tata nilai kerja, yaitu: Integrity, Speed, Smart, Service Excellent (Komptensi inti) dan Efektif, Efisiensi, Inovatif, dan Terintegrasi (Budaya Kerja), maka ditentukan 
tujuan yang hendak dicapai, sasaran kampanye, ruang lingkup kampanye, jangka waktunya, publik sasarannya, tema, topik atau isu dari kampanye, efek yang akan diinginkan dalam suatu kampanye, fasilitas, perlengkapan, atau sarana yang akan menunjang suatu kampanye, dan pembentukan team work yang solid dan profesional.

3. Dalam kampanye perubahan budaya organsiasi ini yang menjadi sasaran adalah seluruh karyawan dengan ruang lingkup kampanye sebatas internal perusahan. Proses kampanye ini memiliki jangka waktu 1 tahun yang dibagi menjadi 2 tahap, yaitu: tahap pertama dimulai bulan Januari hingga Juni 2019 yang telah dilakukan dan tahap kedua akan dilakukan bulan Agustus hingga Desember 2019 dimana public sasarannya yang dituju, yaitu konsumen yang telah menggunakan produk perusahaan atau yang akan menggunakan (konsumen baru). visi, misi, tujuan, sasaran, program kerja, dan tata nilai kerja yang tema/topikyang diangkat sebagai arah kebijakan dan isu perkembangan teknologi menuntut karyawan memiliki kompetensi di era industri 4.0 yang menuntut kemampuan agile dalam beradaptasi dan fleksibel menghadapi perubahan yang begitu cepat dengan menerapkan Integrity, Speed, Smart, Service Excellent (Komptensi inti) dan Efektif, Efisiensi, Inovatif, dan Terintegrasi (Budaya Kerja). Dari kampanye perubahan budaya organisasi ini menghasilkan efek bagi karyawan, yaitu telah mengetahui dan memahami budaya perusahaan terbaru dan apa yang hendak dicapai oleh perusahaan tahun 2020 nanti dan semangat kerja baru yang muncul dalam diri karyawan dimana kehadiran karyawan yang sangat tinggi selama periode Januari-Juni 2019. Kampanye perubahan budaya organisasi ini dilakukan melalui event-event perusahaan, seperti: lomba memasak saat memperingati Hari Kartini, nonton bareng "The Avenger End Game", buka bersama, dan halal bi halal karyawan yang diselenggarakan oleh Departemen SDM, serta Departemen Network \& Marketing yang membawahi staf Public Relations bertugas membuat pesanpesan non verbal dan disebarkan melalui jaringan komunikasi grup whatsapp dan media lainnya. Yang menjadi komunikator adalah direktur dan wakil direktur bidang Umum sebagai merumuskan arah kebijakan perubahan budaya organisasi tersebut. 


\section{DAFTAR PUSTAKA}

\section{Sumber Buku:}

Denzin, Norman dan Lincoln, Yvonna.2009. Handbook of Qualitative Research. Pustaka Pelajar: Yogyakarta.

Hamzah, Amir. 2019. Metode Penelitian Kualitatif Rekonstruksi Pemikiran Dasar serta Contoh Penerapan Pada Ilmu Pendidikan, Sosial \& Humaniora. Malang: Literasi Nusantara.

Handoko, Hani. 2013. Manajemen. Yogyakarta: BPFE

Jefkin dan Yadin. 2003. Public Relation Edisi Kelima. Jakarta: Erlangga.

Kasali, Rhenald. 2016. Manajemen Public Realations. Jakarta: Pustaka Utama Grafiti.

Littlejohn, Stephen dan Foss, Karen. 2011. Teori Komunikasi. Jakarta: Salemba Hunamika.

Mulyana, Dedy. 2009. Ilmu Komunikasi Suatu Pengantar. Bandung: PT Remaja Rosdakarya.

Ndraha, Taliziduhu. 2015. Teori Budaya Organisasi. Jakarta: PT. Rineka Cipta.

Ngalimun. 2017. Ilmu Komunikasi Sebuah Pengantar praktis. Yogyakarta: Pustaka Baru Press.

Pace, Wayne dan Faules, Don. 2018. Komunikasi Organisasi Strategi Meningkatkan Kinerja Perusahaan. Bandung: PT Remaja Rosdakarya.

Ruben, Brent dan Stewart, Lea. 2013. Komunikasi dan Perilaku Manusia. Jakarta: Rajawali Pers.

Ruslan, Rosady. 2015. Kiat dan Strategi Kampanye Public Relations. Jakarta: PT RajaGrafindo Persada.

Sugiyono. 2015. Metode Penelitian Kuantitatif, Kualitatif, dan $R \& D$. Bandung: Alfabeta.

Venus, Antar. 2018. Manajemen Kampanye Panduan Teoritis dan Praktis dalam Mengefektifkan Kampanye Komunikasi Publik. Bandung: Simbiosa Rekatama Media.

Wasesa, Silih Agung dan Macnamara, Jim. 2016. Strategi Public Relations. Jakarta: PT Gramedia Pustaka Utama.

\section{Sumber Riset:}

Gutama, TA. 2010. Peran Komunikasi dalam Organisasi. Jurnal Sosiologi, ISSN: 0215-9635, Vol 25 No. 2 Tahun 2010. Universitas Sebelas Maret.

Ishak, Aswad. 2012. Peran Public Relations dalam Komunikasi Organisasi. Jurnal Komunikasi, Volume 1, Nomor 4, Januari 2012. Universitas Muhammdiyah Yogyakarta.

Putri, Nia Septiana. 2014. Komunikasi Organisasi dalam Mensosialisasikan Budaya Organisasi Prinsip 46 PT. Bank Negara Indonesia (Persero) Tbk. Kantor Cabang Utama Samarinda. Ejournal Ilmu Komunikasi, ISSN: 0000-0000, 2014, 2 (2): 385-399. Universitas Mulawarman. 